\title{
The Mindful Coping Scale: The Validity and Reliability of Turkish Version
}

\author{
Zeynep AKKUŞ ÇUTUK \\ Trakya Üniversitesi, Eğitim Fakültesi, Eğitim Bilimleri Bölümü, Rehberlik ve Psikolojik Danışmanlık Anabilim Dalı, Edirne \\ zeynepacutuk@trakya.edu.tr \\ ORCID ID: https://orcid.org/0000-0001-8364-4431 \\ Tuğba TÜRK \\ Trakya Üniversitesi, Eğitim Fakültesi, Eğitim Bilimleri Bölümü, Rehberlik ve Psikolojik Danışmanlık Anabilim Dalı, Edirne \\ tugbaturk@trakya.edu.tr \\ ORCID ID: https://orcid.org/0000-0002-4361-3769
}

Araştırma Makalesi

DOI: $10.31592 /$ aeusbed.591719

Geliş tarihi: 14.07.2019

Revize Tarihi: 18.11 .2019

Kabul tarihi: 22.11.2019

\section{Atıf Bilgisi}

Akkuş Çutuk, Z. ve Türk, T. (2019). The mindful coping scale: The validity and reliability of Turkish version. Ahi Evran Üniversitesi Sosyal Bilimler Enstitüsü Dergisi, 5(2), 299-311.

\begin{abstract}
In this study, it was aimed to make validity and reliability analyses by adapting the mindful coping scale into Turkish. The scale was enhanced by Tharaldsena and Bruc (2011). The sample group consisted of 283 high school students in the adaptation study. Confirmatory Factor Analysis (CFA) was implemented for construct validity of the scale. DFA results showed that chi-square value $\left(\mathrm{x}^{2}=639.87, \mathrm{~N}=283, \mathrm{df}=221, \mathrm{p}=0.00\right)$ was significant. Fit index values were found to be RMSEA=.076, CFI=.88, IFI=.88, GFI=.85, SRMR=.074. The reliability of the scale was calculated by Cronbach's Alpha Coefficient and Item Total Correlation Coefficient. The Cronbach's Alpha Internal Consistency Reliability Coefficient of the mindful coping scale was found to be .71 for the awareness sub-dimension, .79 for the distraction sub-dimension, .72 for the negative emotion prevention sub-dimension, and .71 for the self-revealing sub-dimension. It was determined that the Mindful Coping Scale of Item-Total Correlations was .31-.57 for the awareness sub-dimension, .33.69 for the distraction sub-dimension, $.38-.53$ for the sub-dimension of prevention of negative emotions, that it ranged from 38 to .59 for constructive self-assertion sub-dimension. According to the results of the study, it can be said that mindful coping scale is a valid and reliable.

Keywords: Mindful coping, validity and reliability, high school students.
\end{abstract}

\section{Bilinçli Başa Çıkma Ölçeği: Türkçe Geçerlik ve Güvenirliği}

\section{ÖZ}

$\mathrm{Bu}$ araştırmada, bilinçli başa çıkma ölçeğinin Türkçeye uyarlanarak geçerlik ve güvenirlik analizlerini yapmak hedeflenmiştir. Ölçek Tharaldsena ve Bruc (2011) tarafından geliştirilmiştir. Uyarlama çalışmasında örneklem grubunu 283 lise öğrencisi oluşturmaktadır. Bilinçli başa çıkma ölçeğinin yap1 geçerliliği için Doğrulayıcı Faktör Analizi (DFA) uygulanmıştır. DFA'nın ardından ki-kare değerinin $\left(\mathrm{x}^{2}=639.87, \mathrm{~N}=283\right.$, $\mathrm{df}=221, \mathrm{p}=0.00$ ) anlamlı sonuç verdiği belirlenmiştir. Uyum indeks değerlerinin RMSEA=.076, CFI $=.88$, $\mathrm{IFI}=.88, \mathrm{GFI}=.85, \mathrm{SRMR}=.074$ olduğu saptanmıştır. Ölçeğin güvenirliği Cronbach's Alfa Katsayısı ve Madde Toplam Korelasyon Katsayısı ile hesaplanmıştır. Bilinçli başa çıkma ölçeğinin Cronbach's Alfa İç Tutarlılık Güvenirlik Katsayısı farkındalık alt boyutu için .71, dikkati dağıtma alt boyutu için .79, olumsuz duyguları önleme alt boyutu için .72, kendini yapıcı olarak ortaya koyma alt boyutu için .71 olarak bulunmuştur. Madde-Toplam Korelasyonlarının Bilinçli başa çıkma ölçeği farkındalık alt boyutu için .31-.57, dikkati dağıtma alt boyutu için .33-.69, olumsuz duyguları önleme alt boyutu için .38-.53, kendini yapıcı olarak ortaya koyma alt boyutu için $.38-.59$ arasında değiştiği saptanmıştır. Çalışmadan elde edilen sonuçlara göre bilinçli başa çıkma ölçeğinin geçerli ve güvenilir olduğu söylenebilir.

Anahtar Kelimeler: Bilinçli başa çıkma, geçerlik ve güvenirlik, lise öğrencileri.

\section{Introduction}

It is seen that terms such as staying at the moment, being here and now, accepting, showing self compassion, not judging, courtesy and attention are used quite often. Mindful awareness comes up as a concept that meets these terms. Mindful awareness is rooted in Buddhist and another active mindful customs of mindful attention and awareness (Brown and Ryan, 2003). Mindful awareness is related to awakening and living in harmony with oneself and with the world. Mindful awareness involves developing appreciation for the fullness of every moment of life. In mindful awareness, knowing, experiencing the present and attention without judging is the matter. It also includes clarity, 
acceptance and awareness. It emphasizes that life is only moments. With mindful awareness, one gets in touch with his wisdom and vitality by getting rid of troubles (Kabat-Zinn, 2001). With mindful awareness, instead of worrying about the past or worrying about the future, how to live now is explored in an entertaining way (Alidina, 2010). Mindful awareness moments are now centred, uncritical, deliberate, nonverbal, being in discovery, and witnessing (Germer, 2005a).

It is seen that overlapping and differentiating definitions are made by different authors. According to Brown and Ryan (2003), it is a state of attention and awareness of what is currently happening. Kabat-Zinn (2003), on the other hand, defines it as an awareness springing in relation to a moment of experience right now and in a non-judgemental way. For Bishop, Lau, Shapiro, Carlson, Anderson, Carmody and Devins (2004), the mindfullness is on directing the focus of attention to what happened at that moment with clear curiosity and attention. Germer (2005a) describes it as being aware of the experience of the present moment in a friendly way, with courtesy, without judgment and with acceptance. There are also descriptions of it as a careful attention and awareness of current incidents and experiences (Brown, Ryan and Creswell, 2007); to mindfully pay attention to the present time with qualities such as compassion, curiosity and acceptance (Alidina, 2010); a strong awareness of the mental and physical events that occur in and around itself (Harvey, 2000); deliberately paying attention to current experiences of compassion, curiosity, acceptance, and openness (Alidina and Marshall, 2013), a form of present deliberate mindfulness, awareness, or cautiousness that can be learned through meditation (Jabos and Blustein, 2018). Bruna (2018) claims that mindful awareness is much more than present-day awareness. According to him, mindful awareness includes concentration, wisdom and the ability to develop and facilitate healthy choices that promote true happiness and meaningful life.

While mindful awareness seems simple as staying in the moment and paying attention to what is happening, it forces one because it involves not automatically reacting (Alidina and Marshall, 2013). It is also not being in a state of dreaming. Mindful awareness is especially used to reduce the pain of the difficulties of a self-exposed life (Germer, 2005a).

It is suggested that mindful awareness has three basic interdependent elements: awareness, present and acceptance. Awareness includes stopping, observing and return. Stopping is a way to prepare for mindful awareness. Adequate instant interruptions are necessary for mindful awareness. In mindful awareness, experiences are observed objectively and independently. It is also important to get rid of rumination here. Attention means the method of concentrating on mindful awareness, being highly sensitive to a restricted experience and focusing on breath. In the return phase, it is necessary to be awakened. Waking up is an instant awareness. When a person plunges into daily activity, he or she may want to slow down or stop again. All mindful awareness exercises draw attention to the present moment. Everything happens in the present. If our attention is missed by a strong sensation or feeling, we lose the moment. The only reason for returning to breath or another object is to find our attention again, focus on something concrete. From the point of view of acceptance, it is seen that most people lack acceptance and therefore their awareness. Yet acceptance is a soft, gentle and comfortable content (Germer, 2005b; Westen, 1999). Some authors (Averill, 1992; Mayer, Chabot and Carlsmith, 1997) distinguished mindfulness from other forms of mental processing (i.e., cognition, motives, and emotions) that enable people to function effectually. In this way, one can be aware of sensory, perceptual stimuli as well as thoughts, motives and emotions. Mindfulness involves both awareness and attention. Awareness functions as a radar in the background of mindfulness that constantly monitors the internal and external systems. Stimuli may not be realized even if they are not in the centre of attention. Bishop et al. (2004) offered a two-component awareness model. The initial element includes self-regulation process of attention, thus ensuring immediate experience and recognition of current mental occurrences. The second component involves the adoption of a particular orientation, curiosity, openness and acceptance towards the person's experiences at the present time.

Mindful awareness contrastingly cannot be dissociated from action and it may provide one of the biggest means of survival in an unpredictable, difficult and complicated world (Jabos and Blustein, 2018). Mindful awareness in itself is problem-oriented and increases coping with emotions (Halland, 
de Vibe, Solhaug, Friborg, Rosenvinge, Tyssen, Sørlie and Bjørndal, 2015; Tharaldsena and Bruc, 2011).

There are many measurement tools used to measure mindful attention in our country (The Mindful Attention Awareness Scale, The Cognitive and Affective Mindfulness Scale, The Mindfulness in Parenting Questionnaire, Inventory of Mindfulness Experiences-Adolescents, The Mindfulness in Teaching Scale etc.). However, these tools directly aim to measure mindful attention and are mostly intended for adults. It was determined in the literature that there was no measurement tool that measures coping based on mindful attention among adolescents. In this study, it was aimed to adapt the mindful coping scale to Turkish. It is considered that the scale's focusing on direct mindful coping is important especially in school counselling and therapies, in terms of examining the development of coping skills towards the negative experiences of the clients.

\section{Methodology}

\section{Research Model}

This study is a descriptive study to detect the psychometric particulars of mindful coping scale. Mindful coping scale was developed by Tharaldsena and Bruc (2011). The study was conducted on 690 students aged 16 to 20 years. In the scale development stage, Cronbach's alpha internal consistency reliability coefficient, Pearson moments multiplication correlation coefficient, exploratory and confirmatory factor analysis were performed. Item pool consisting of 30 questions was created for the scale. The scale was decided to have 4 sub-dimensions: awareness, distraction, prevention of negative emotions and constructive self-assertion. To evaluate the unidimensionality or homogeneity of the four sub-dimensions of the scale, an exploratory factor analysis (EFA) of the items constituting every component was performed. According to the results, the eigenvalues of the four factors vary between 1.73 and 6.44 and the items in the scale explain 56\% of the total variance. Seven items were removed from the scale due to lack of desired factor loads and the scale was finalized with a total of 23 items.

In consequence of confirmatory factor analysis, goodness of fit indexes were found to be acceptable (Chi-square $=632.2, d f=222$, PGFI (Parsimony Goodness of Fit Index) $=0.74$, GFI $($ Goodness of Fit Index $)=0.93$, TLI $($ Tucker Lewis Index $)=0.92$, CFI $($ Comparative Fit Index $)=0.93$, RMSEA (Root Mean Square Error of Appreciation) $=0.05$; 90\% CI 0.047-0.057). As a result of the analyses, a structure including 23 items and 4 factors was confirmed. The Cronbach's Alpha Internal Consistency Reliability Coefficient of the mindful coping scale was found to be .83 for the awareness sub-dimension, .85 for the distraction sub-dimension, .76 for the prevention of negative emotions subdimension, and .84 for the constructive self-assertion sub-dimension.

To estimate the criterion-related validity of the mindful coping scale, its relationship with the short coping scale was investigated. Accordingly, it was found that the awareness sub-dimension of the mindful coping scale was mostly associated with problem-focused coping and emotion-focused coping, the distraction subscale was associated with the strongest emotion-focused coping, and it has a weak relationship with problem-focused coping. It was determined that the prevention of negative emotions sub-dimension of the mindful coping scale was mostly associated with problem-oriented coping and had a weak relationship with coping avoidance. The constructive self-assertion subdimension was found to be associated with problem-oriented coping and partially related with emotion-oriented coping.

\section{Study Group}

This study was conducted on 283 students [20 (42.4\%) male and 163 (57.5\%) female] in Anatolian High School in 2018-2019 academic year. In addition, the scale's linguistic validity study was conducted on 32 English teachers, test-retest studies on 86 high school students, and criterionrelated validity study on 149 high school students. 


\section{Data Collection Tools}

\section{Mindful Coping Scale}

Mindful coping scale was developed by Tharaldsena and Bruc (2011). The scale consists of 23 items and 4 sub-dimensions [awareness $(1,2,3,4,5,6$,$) , distraction (7,8,9,10,11,12,13,14)$, preventing negative emotions $(15,16,17,18)$ and constructive self-assertion $(19,20,21,22,23)]$. Scoring of the scale is done as 1 never, 5 always. Each sub-dimension score is obtained by addition of the relevant items. The highness of the score expresses that the relevant coping approach is used more.

\section{Coping Scale for Adolescents}

The validity and reliability of the Turkish version of the coping scale for adolescents developed by Spirito, Stark and Williams (1988) was made by Bedel, Işık and Hamarta (2014). The scale consists of 11 items and 3 sub-dimensions (active coping, avoiding coping and negative coping). Scoring of the scale is done as 0 never, 3 almost always. The scores that can be obtained vary between 0-12 for active coping and avoiding coping and 0-9 for negative coping. The highness of the score expresses that the relevant coping approach is used more. As a result of the criterion-related validity, it was found that there was a moderate relationship between sub-dimensions of coping scale and trait anxiety for adolescents. The internal consistency reliability coefficient of the scale was .72 for active coping, .70 for avoiding coping, and .65 for negative coping. The test-retest reliability coefficient, which was conducted with 3 -week intervals was $r=.66$ for active coping, $r=.61$ for avoiding coping and $\mathrm{r}=.76$ for negative coping.

\section{Procedure}

To detect the psychometric properties of the mindful coping scale, Kjersti B. Tharaldsen was gotten in touch with via e-mail and necessary permission was obtained for the use of the scale. The process of translating the mindful coping scale into Turkish was realized in certain stages. First of all, the scale was translated into Turkish by five academicians working in the department of English Language Teaching, then this Turkish form was translated back to English and the consistency between the two forms was evaluated. These academicians made the necessary arrangements in terms of meaning and grammar by discussing the Turkish form and the Turkish form was finalized. Finally, this form was reviewed by three academicians in the field of guidance and psychological counselling, and the necessary changes were made. Before starting the validity and reliability studies, a linguistic equivalence study was conducted to examine the consistency between the Turkish form and the original form of the mindful coping scale. For this purpose, both forms were applied to 32 English teachers. As a result, Turkish and English forms were found to be equivalent.

In order to apply the scale to high school students, firstly the approval of the Provincial Directorate of National Education was obtained. The school where the study would be conducted was choosed selected by random sampling method. Prior to the implementation, the appropriate day for the research was determined by interviewing the authorities of the relevant school. The scale was applied to $11^{\text {th }}$ and $12^{\text {th }}$ grade students in the school on the specified day. Missing and sloppy forms were identified during the application process and these forms were removed from the research and the total number of students included in the research was 283. SPSS 20 and LISREL 8.8 package programs were used for the analysis of the data obtained from the validity and reliability studies of the scale.

Confirmatory factor analysis (CFA) was performed for the construct validity of the scale. On the other hand, CFA is made on the basis of a theoretical basis to assess the degree to which the factors formed from various variables match the actual data. In other words, the extent to which a predetermined or constructed structure is verified by the collected data is examined in CFA (Büyüköztürk, Akgün, Kahveci and Demirel, 2004). 


\section{Findings}

\section{Linguistic Validity}

According to the findings obtained from the linguistic validity of the mindful coping scale, the relationship between Turkish and original form scores was .92 for the awareness sub-dimension, .91 for the distraction sub-dimension, .87 for the preventing negative emotions sub-dimension, and .90 for the constructive self-assertion sub-dimension. The conclusions are indicated in Table 1.

Table 1

Mindful Coping Scale Linguistic Validity Findings

\begin{tabular}{llccc}
\hline Factor & Execution & X & Ss & r \\
\hline \multirow{2}{*}{ Awareness } & English Form & 20.46 & 3.21 & .92 \\
\multirow{2}{*}{ Distraction } & Turkish form & 20.06 & 3.39 & \\
& English Form & 22.15 & 5.02 & .91 \\
\multirow{2}{*}{ Preventing negative emotions } & Turkish form & 22.03 & 5.13 & \\
& English Form & 15.31 & 3.16 & .87 \\
Constructive self-assertion & Turkish form & 15.78 & 3.52 & \\
& English Form & 17.96 & 2.95 & .90 \\
\hline
\end{tabular}

\section{Construct Validity}

This study aimed to establish validity for mindful coping scale through confirmatory factor analysis. In this study, chi-square value $\left(\mathrm{x}^{2}=639.87, \mathrm{~N}=283, \mathrm{df}=221, \mathrm{p}=0.00\right)$ was found to be significant. Fit index values were detect to be RMSEA=.076, CFI $=.88$, IFI=.88, GFI=.85, $\mathrm{SRMR}=.074$. İn consequence of the analysis, it is seen that the scale has adequate fit values and mindful coping scale is a valid tool. Path Diagram and Factor Loads of the Model are shown in Figure 1. In addition, the $t$ values between the factors and the items were examined and shown in Figure 2. In this model, all items were found to be compatible with the model being constructed and tested. 


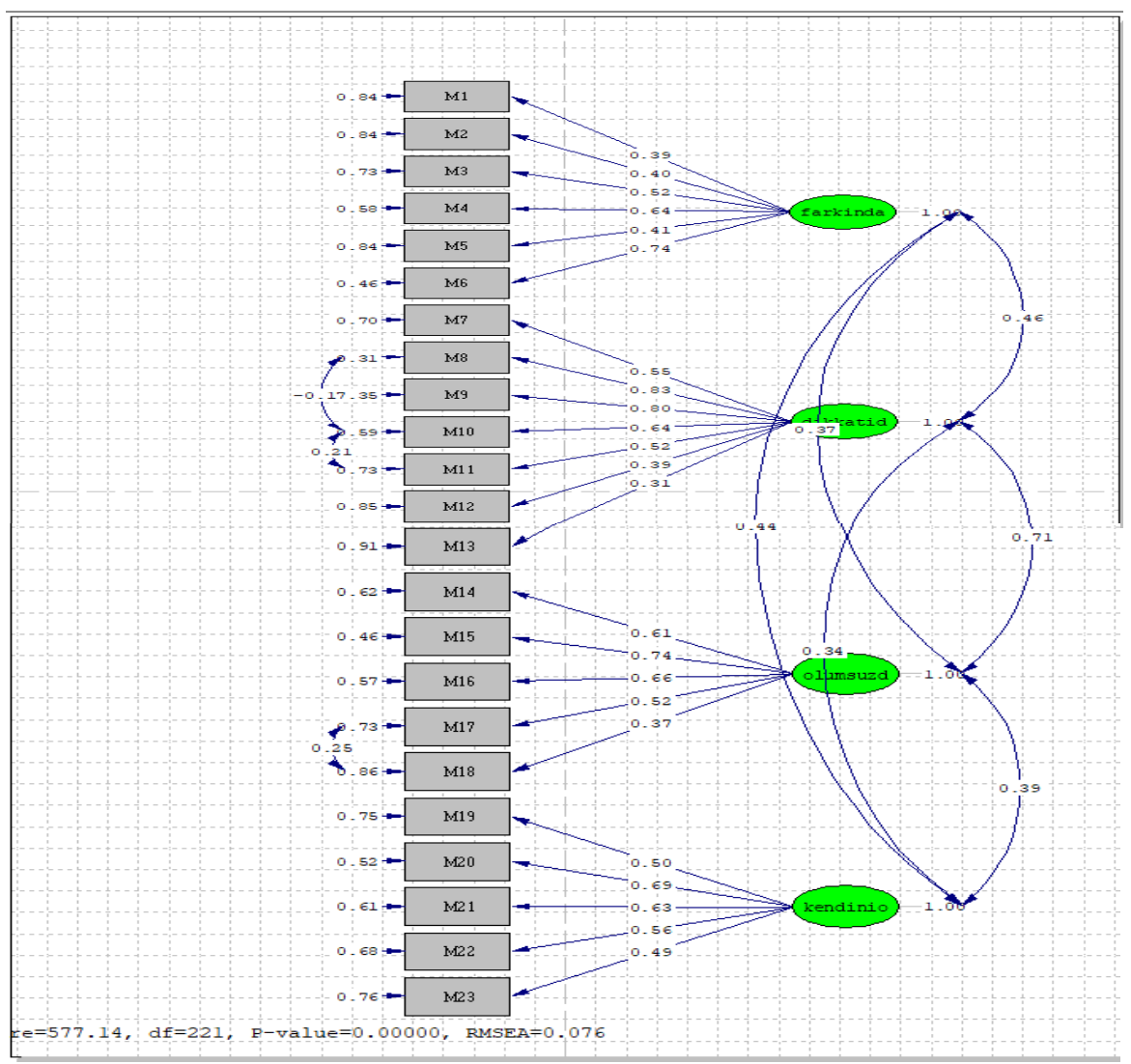

Figure 1. Factor Loads of the Model and Path Diagram

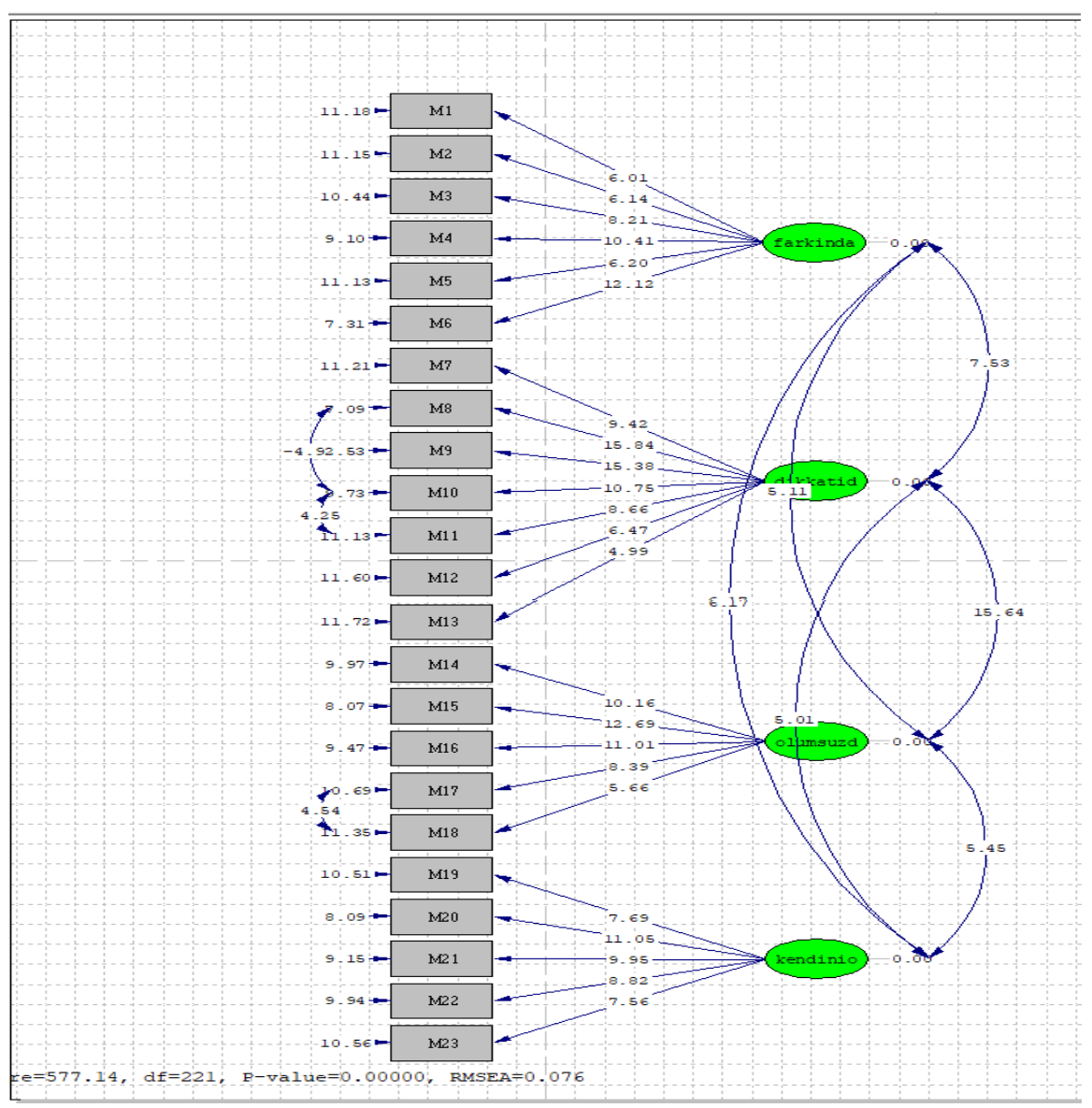

Figure 2. The t Values Between the Factors and the Items 


\section{Criterion Relative Validity}

For the criterion-relative validity of mindful coping scale, its relationship with the coping scale for adolescents was examined. Table 2 shows the correlation coefficients and descriptive statistics between the sub-dimensions of the scales.

Table 2

Correlation Coefficients and Descriptive Statistics Between the Sub-Dimensions of the Scales

\begin{tabular}{|c|c|c|c|c|c|c|c|c|}
\hline & & Awareness & Distraction & $\begin{array}{l}\text { Preventing } \\
\text { negative } \\
\text { emotions }\end{array}$ & $\begin{array}{l}\text { Constructive } \\
\text { self-assertion }\end{array}$ & $\begin{array}{l}\text { Active } \\
\text { coping }\end{array}$ & $\begin{array}{l}\text { Avoiding } \\
\text { coping }\end{array}$ & $\begin{array}{c}\text { Negative } \\
\text { coping }\end{array}$ \\
\hline \multirow{4}{*}{ Awareness } & Correlation(r) & 1 & & & & & & \\
\hline & Significance(p) & & & & & & & \\
\hline & $\mathrm{N}$ & 149 & & & & & & \\
\hline & Correlation(r) & $.309^{* *}$ & 1 & & & & & \\
\hline \multirow[t]{2}{*}{ Distraction } & Significance(p) & .000 & & & & & & \\
\hline & $\mathrm{N}$ & 149 & 149 & & & & & \\
\hline \multirow{4}{*}{$\begin{array}{l}\text { Preventing } \\
\text { negative } \\
\text { emotions }\end{array}$} & Correlation(r) & .335 & .463 & 1 & & & & \\
\hline & Significance(p) & .000 & .000 & & & & & \\
\hline & $\mathrm{N}$ & 149 & 149 & 149 & & & & \\
\hline & Correlation(r) & $.436^{* *}$ & $.261^{* *}$ & .096 & 1 & & & \\
\hline \multirow{2}{*}{$\begin{array}{l}\text { Constructive } \\
\text { self-assertion }\end{array}$} & Significance(p) & .000 & .001 & .242 & & & & \\
\hline & $\begin{array}{c}\mathrm{N} \\
\text { Correlation(r) }\end{array}$ & $\begin{array}{r}149 \\
.266^{* *}\end{array}$ & $\begin{array}{r}149 \\
.405^{* *}\end{array}$ & $\begin{array}{r}149 \\
.399^{* *}\end{array}$ & $\begin{array}{r}149 \\
.231^{* *}\end{array}$ & 1 & & \\
\hline \multirow{2}{*}{$\begin{array}{l}\text { Active } \\
\text { coping }\end{array}$} & Significance(p) & .001 & .000 & .000 & .005 & & & \\
\hline & $\begin{array}{c}\mathrm{N} \\
\text { Correlation(r) }\end{array}$ & $\begin{array}{r}149 \\
.030\end{array}$ & $\begin{array}{r}149 \\
.118\end{array}$ & $\begin{array}{r}149 \\
.049\end{array}$ & $\begin{array}{r}149 \\
.058\end{array}$ & $\begin{array}{r}149 \\
-.051\end{array}$ & 1 & \\
\hline \multirow{2}{*}{$\begin{array}{l}\text { Avoiding } \\
\text { coping }\end{array}$} & Significance(p) & .715 & .153 & .554 & .479 & .537 & & \\
\hline & $\begin{array}{c}\mathrm{N} \\
\text { Correlation(r) }\end{array}$ & $\begin{array}{r}149 \\
-.098\end{array}$ & $\begin{array}{r}149 \\
-.129\end{array}$ & $\begin{array}{r}149 \\
-.111\end{array}$ & $\begin{array}{r}149 \\
-.029\end{array}$ & $\begin{array}{r}149 \\
-.252^{* *}\end{array}$ & $\begin{array}{r}149 \\
.312^{* *}\end{array}$ & 1 \\
\hline \multirow{2}{*}{$\begin{array}{l}\text { Negative } \\
\text { coping }\end{array}$} & Significance(p) & .234 & .117 & .178 & .727 & .002 & .000 & \\
\hline & $\mathrm{N}$ & 149 & 149 & 149 & 149 & 149 & 149 & 149 \\
\hline \multirow{2}{*}{\multicolumn{2}{|c|}{$\begin{array}{l}\text { Mean } \\
\text { Standard deviation }\end{array}$}} & 19.19 & 26.10 & 11.43 & 18.63 & 7.47 & 6.82 & 2.76 \\
\hline & & 3.25 & 5.98 & 3.45 & 3.64 & 2.04 & 1.85 & 1.77 \\
\hline \multicolumn{2}{|c|}{ Minimum } & 11 & 9 & 4 & 9 & 2 & 0 & 0 \\
\hline Maximum & & 28 & 40 & 20 & 25 & 12 & 12 & 8 \\
\hline
\end{tabular}

$* * \mathrm{p}<0.01$

As shown in Table 2, a positive correlation was detected between the sub-dimensions of the mindful coping scale and the active coping sub-dimension of the coping scale for adolescents (between .23 and .40). However, there was no correlation between avoiding coping and negative coping sub-dimensions.

\section{Reliability and Item Analysis}

In consequence of the analyses, the Cronbach's Alpha Internal Consistency Reliability Coefficient of the mindful coping scale was found to be .71 for the awareness sub-dimension, .79 for the distraction sub-dimension, .72 for the sub-dimension of prevention of negative emotions, and .71 for constructive self-assertion sub-dimension. It was determined that mindful coping scale of ItemTotal Correlations were .31-.57 for the awareness sub-dimension, .33-.69 for the distraction sub- 
dimension, .38-.53 for the sub-dimension of prevention of negative emotions, .38 to .59 for the constructive self-assertion sub-dimension. Item-total correlations of the scale are shown in Table 3 below. For the test-retest reliability study, the Turkish version of the mindful coping scale was administered twice to 86 high school students at 3 -week intervals. Test-retest reliability coefficients of the scale are presented in Table 4.

Table 3

Item-Total Correlations of the Mindful Coping Scale

\begin{tabular}{|c|c|c|}
\hline & Items & $\begin{array}{l}\text { Item-total } \\
\text { correlations }\end{array}$ \\
\hline \multirow{6}{*}{ Awareness } & 1 & .360 \\
\hline & 2 & .446 \\
\hline & 3 & .485 \\
\hline & 4 & .553 \\
\hline & 5 & .316 \\
\hline & 6 & .578 \\
\hline \multirow{7}{*}{ Distraction } & 7 & .466 \\
\hline & 8 & .655 \\
\hline & 9 & .692 \\
\hline & 10 & .531 \\
\hline & 11 & .553 \\
\hline & 12 & .455 \\
\hline & 13 & .338 \\
\hline \multirow{5}{*}{ Preventing negative emotions } & 14 & .464 \\
\hline & 15 & .537 \\
\hline & 16 & .533 \\
\hline & 17 & .503 \\
\hline & 18 & .389 \\
\hline \multirow{5}{*}{ Constructive self-assertion } & 19 & .422 \\
\hline & 20 & .592 \\
\hline & 21 & .544 \\
\hline & 22 & .453 \\
\hline & 23 & .387 \\
\hline
\end{tabular}


Table 4

Test-Retest Reliability Coefficients of the Mindful Coping Scale

\begin{tabular}{llccc}
\hline Factor & Execution & $\mathrm{X}$ & $\mathrm{Ss}$ & $\mathrm{r}$ \\
\hline \multirow{2}{*}{ Awareness } & First execution & 17.62 & 4.72 & .74 \\
& Second execution & 19.61 & 6.19 & .74 \\
Distraction & First execution & 24.80 & 6.14 & \\
& Second execution & 23.77 & 5.73 & .72 \\
Preventing negative emotions & First execution & 10.75 & 3.25 & \\
& Second execution & 11.60 & 4.04 & .69 \\
Constructive self-assertion & First execution & 19.15 & 3.88 & \\
& Second execution & 18.31 & 3.94 & .70 \\
\hline
\end{tabular}

\section{Discussion and Conclusion}

The aim of this study is to adapt the mindful coping scale developed by Tharaldsena and Bruc (2011) to the Turkish version and to make validity and reliability analyses of the scale. Mindful coping scale consists of 23 items and 4 sub-dimensions (awareness, distraction, preventing negative emotions and constructive self-assertion). The scale is a 5 point likert scale. Scoring of the scale is done as 1 never, 5 always.

Confirmatory factor analysis was conducted to test the construct validity of the scale. Regarding the values obtained in CFA, in the literature, the fact that the ratio obtained by dividing the value of X2 by the degree of freedom is two or less states that the model is a good model and a value of five or less states an acceptable goodness of fit. It is argued that for acceptable fitness for RFI, CFI, NFI, NNFI and IFI it should be $\geq .90$ and for perfect fitness, it should be $\geq .95$, for GFI and AGFI for acceptable fitness it should be $\geq .85$ and for perfect fitness it should be $\geq .90$ and for RMR, REMSEA and SRMR for acceptable fitness it should be $\leq .08$ and for perfect fitness it should be $\leq .50$ (Hu and Bentler, 1999; Marcoulides and Schumacher, 2001; Schermelleh-Engel and Moosbrugger, 2003; Schumacher and Lomax, 2004). Accordingly, the chi-square value $\left(\mathrm{x}^{2}=639.87, \mathrm{~N}=283, \mathrm{df}=221, \mathrm{p}\right.$ $=0.00)$ was significant in consequence of CFA, and the values of the fit indexes (RMSEA $=.076$, CFI $=.88, \mathrm{IFI}=.88, \mathrm{GFI}) .=.85, \mathrm{SRMR}=.074$ ) were at an adequate level.

The reliability of the scale was tested with Cronbach's Alpha Coefficient and item total correlation. Since Cronbach's Alpha value was accepted to be at least .70 and higher in the scale studies (Seçer, 2015) .71 for the awareness sub-dimension, .79 for the distraction sub-dimension, .72 for the prevention of negative emotions sub-dimension, .71 for the constructive self-assertion subdimension can be said to be high for internal consistency level. Considering that items with .30 and higher in terms of item-total correlation differentiate individuals well in terms of measured quality (Büyüköztürk, 2015), .31-.57 for awareness sub-dimension, .33-.69 for distraction sub-dimension, .38.53 for prevention of negative emotions sub-dimension and .38-.59 for constructive self-assertion subdimension can be considered adequate.

The results of the research indicate that the Turkish form of the mindful coping scale is a valid and reliable measurement tool for high school students. In this sense, mindful coping scale could be used in studies for high school students. It is evaluated that the use of the mindful coping scale in larger and different samples, in clinical areas and in researches in which cultural comparisons are made will provide significant benefits to the literature. 


\section{References}

Alidina, S. (2010). Mindfulness for dummies. West Sussex: John Wiley and Sons.

Alidina, S. and Marshall, J.J. (2013). Mindfulness workbook for dummies. West Sussex: John Wiley and Sons.

Averill, J. R. (1992). The structural bases of emotional behavior: A metatheoretical analysis. Review of Personality and Social Psychology, 13, 1-24.

Bedel, A., Işık, E. ve Hamarta, E. (2014). Ergenler İçin Başa Çıkma Ölçeğinin (EBÇÖ) geçerlik ve güvenirlik çalışması. Eğitim ve Bilim, 39(176), 227-235.

Bishop, S. R., Lau, M., Shapiro, S., Carlson, L., Anderson, N. D., Carmody, J. and Devins, G. (2004). Mindfulness: A proposed operational definition. Clinical Psychology: Science and Practice, $11,230-241$.

Büyüköztürk, Ş., Akgün, Ö., Kahveci, Ö. ve Demirel, F. (2004). Güdülenme ve öğrenme stratejileri ölçeği'nin türkçe formunun geçerlik ve güvenirlik çalışması. Kuram ve Uygulamada Ĕgitim Bilimleri, 4(2), 207-239.

Büyüköztürk, Ş. (2015). Sosyal bilimler için veri analizi el kitabı (21. Bask1). Ankara: Pegem Akademi.

Brown, K. W. and Ryan, R. M. (2003). The benefits of being present: Mindfulness and its role in psychological well-being. Journal of personality and social psychology, 84(4), 822-848.

Brown, K. W., Ryan, R. M. and Creswell, J. D. 2007. Mindfulness: Theoretical foundations and evidence for its salutary effects. Psychological Inquiry, 18, 211-237.

Bruna, J. (2018). The essential guidebook to mindfulness in recovery. Las Vegas: Central Recovery Press.

Germer, C. K. (2005a). Mindfulness: What is it? What does it matter? In C. K. Germer, R. D. Siegel and P. R. Fulton (Eds.), Mindfulness and psychotherapy (p. 3-27). New York: Guilford Press.

Germer, C. K. (2005b). Teaching mindfulness in therapy. In C. K. Germer, R. D. Sie-gel and P. R. Fulton (Eds.), Mindfulness and psychotherapy (p. 113-129). New York: Guilford Press.

Halland, E., de Vibe, M., Solhaug, I., Friborg, O., Rosenvinge, J. H., Tyssen, R., Sørlie, T. and Bjørndal, A. (2015). Mindfulness training improves problem-focused coping in psychology and medical students: Results from a randomized controlled trial. College Student Journal, 49(3), 387-398.

Harvey, P. (2000). An introduction to Buddhist ethics: Foundations, values and issues. Cambridge, UK: Cambridge University Press.

Hu, L. T. and Bentler, P. M. (1999). Cut off criteria for fit indexes in covariance structural analysis: Conventional criteria versus new alternatives. Structural Equation Modeling, 6(1), 55-65.

Jacobs, S. J. and Blustein, D. L. (2008). Mindfulness as a coping mechanism for employment uncertainty. The Career Development Quarterly, 57(2), 174-180.

Kabat-Zinn, J. (2001). Mindfulness meditation in everyday life. London: Piatkus Books. 
Kabat-Zinn, J. (2003). Mindfulness-based interventions in context: Past, present, and future. Clinical Psychology: Science and practice, 10(2), 144-156.

Marcoulides, G. and Schumacher, R. (2001). New developments and techniques in structural equation modeling. London: Lawrence Erlbaum Associates, Publishers.

Mayer, J. D., Chabot, H. F. and Carlsmith, K. (1997). Conation, affect, and cognition in personality. In G. Matthews (Ed.), Cognitive science perspectives on personality and emotion (p. 31-63). Amsterdam: Elsevier.

Seçer, İ. (2015). Psikolojik test geliştirme ve uyarlama süreci. Ankara: Anı Yayınc1lı.

Schermelleh-Engel, K. and Moosbrugger, H. (2003). Evaluating the fit of structural equation models: Tests of significance and descriptive goodness-of-fit measures. Methods of Psychological Research Online, 8(2), 23-74.

Schumacher, R. and Lomax, R. (2004). A beginner's guide to structual equation modelling. London: Lawrence Erlbaum Associates, Publishers.

Şimşek, Ö. F. (2007). Yapısal eşitlik modellemesine giriş temel ilkeler ve LISREL uygulamaları. Ankara: Ekinoks Yayınları.

Tharaldsena, K.B. and Bruc, E. (2011). Validation of the mindful coping scale. Emotional and Behavioural Difficulties, 16(1), 87-103.

Thondup, T. (1996). The healing power of mind. London, UK: Penguin.

Westen, D. (1999). Psychology: Mind, brain, and culture (2nd ed). New York: Wiley. 


\section{Genişletilmiş Özet}

\section{Giriş}

Anda kalmak, şimdi ve burada olmak, kabullenmek, kendine şefkat göstermek, yargılamamak, nezaket ve dikkat gibi terimlerin oldukça sık bir şekilde kullanıldığı görülmektedir. Bu terimleri karşılayan kavram olarak ise bilinçli farkındalık kavramı gündeme gelmektedir. Bilinçli farkındalık, köklerini Budist ve bilinçli dikkat ve farkındalığın aktif diğer düşünce geleneklerinden almaktadır (Brown ve Ryan, 2003). Bilinçli farkındalığın, kişinin kendisiyle ve dünyayla uyum içinde uyanması ve yaşamasıyla ilgisi vardır. Bilinçli farkındalık, hayatın her anının doluluğu ile ilgili takdir geliştirmeyi içermektedir. Bilinçli farkındalıkta bilerek, şu anı yaşayarak ve yargılamadan dikkat söz konusudur. Ayrıca netlik, kabul ve farkındalığı da içermektedir. Hayatın anlardan ibaret olduğunu vurgulamaktadır. Bilinçli farkındalıkla kişi, sıkıntılardan kurtularak; kendi bilgelik ve canlılığı ile temasa geçmektedir (Kabat-Zinn, 2001). Bilinçli farkındalıkla birlikte, geçmiş hakkında endişelenmek veya gelecekle ilgili endişe etmek yerine, şu anda nasıl yaşanacağı eğlenceli bir şekilde keşfedilir (Alidina, 2010). Bilinçli farkındalıklı anlar, şimdi merkezli, eleştirisiz, kasıtlı, sözsüz, keşif halinde olma, şahit olma gibi özellikler göstermektedir (Germer, 2005a). Farklı yazarlar tarafindan birbirleriyle örtüşen ve ayrışan tanımlar yapıldığ 1 görülmektedir. Brown ve Ryan'a (2003) göre, şu anda neler olup bittiğine dikkat etme ve farkında olma durumudur. Kabat-Zinn (2003) ise bilerek, şu anda ve yargılayıcı olmayan bir şekilde, deneyim anı yaşanmasıyla ilgili ortaya çıkan farkındalık olarak tanımlamaktadır. Bishop vd. (2004) içinse açık bir merak ve dikkatle mevcut anın deneyimine dikkatin odağının yönlendirilmesidir. Germer (2005a) dostça, nezaketle, yargısızca ve kabulle mevcut anın deneyiminin farkında olmak şeklinde tanımlamaktadır. Şu andaki olaylara ve deneyimlere karşı duyarlı bir dikkat ve farkındalık (Brown, Ryan, ve Creswell, 2007); şefkat, merak ve kabul gibi niteliklerle şu andaki zamana bilinçli bir şekilde dikkat etmek (Alidina, 2010); kendi içinde ve çevresinde ortaya çıkan zihinsel ve fiziksel olayların güçlü bir farkındalık hali (Harvey, 2000); kasten şu andaki şefkat, merak, kabul ve açıklık ile ilgili deneyimlere dikkat etme (Alidina ve Marshall, 2013), meditasyon yoluyla öğrenilebilecek şu anda olan bir tür kasıtlı bilinçlilik, farkındalık veya dikkatli olma biçimi (Jabos ve Blustein, 2018) şeklindeki tanımlan da mevcuttur. Bruna (2018) ise bilinçli farkındalığın şimdiki zaman farkındalığından çok daha fazlası olduğunu iddia etmektedir. Ona göre bilinçli farkındalık konsantrasyon, bilgelik ve gerçek mutluluğu ve anlamlı bir yaşamı teşvik eden sağlıklı seçimler yapma yeteneğini geliştirmeyi ve kolaylaştırmayı içermektedir. Bilinçli farkındalık anda kalmak ve olan bitene dikkat etmek gibi basit görünmesine rağmen, otomatik olarak tepki vermemeyi içerdiğinden kişiyi zorlamaktadır (Alidina ve Marshall, 2013). Ayrıca bir hayal kurma durumunda olmamaktır. Bilinçli farkındalık özellikle kendi kendine maruz bırakılan yaşamın zorluklarının acısını azaltmak için kullanılmaktadır (Germer, 2005a). Bilinçli farkındalık, paradoksal olarak, eylemle birlikte var olur ve dengesiz, karmaşık ve zorlu bir dünyada hayatta kalmak için en büyük araçlardan biri olabilir (Jabos ve Blustein, 2018). Bilinçli farkındalık başlı başına problem odaklı ve duygu başa çıkmayı artırmaktadır (Hallan vd., 2015; Tharaldsena ve Bruc, 2011). Bu çalışma kapsamında ise bilinçli başa çıkma ölçeğinin Türkçe'ye uyarlanması amaçlanmıştır. Ölçeğin doğrudan bilinçli başa çıkmaya odaklanmasının bu ölçeğin özellikle okul danışmanlığında ve terapilerde danışanların olumsuz yaşantılarına yönelik baş etme becerilerinin gelişim seyrini incelemek açısından önemli olduğu düşünülmektedir.

\section{Yöntem}

$\mathrm{Bu}$ araştırmanın amacı Tharaldsena ve Bruc (2011) tarafından geliştirilen bilinçli başa çıkma ölçeğini Türkçeye uyarlamak ve ölçeğin geçerlik ve güvenirlik analizlerini yapmaktır. Araştırma, bilinçli başa çıkma ölçeğinin psikometrik özelliklerini belirlemek amacıyla yapılan betimsel bir çalışmadır. Araştırma, 2018-2019 eğitim öğretim yılında Anadolu Lisesinde öğrenim gören 120'si (\%42.4) erkek, 163'ü (\%57.5) kadın olmak üzere toplam 283 öğrenci üzerinde yürütülmüsstür. Ayrıca ölçeğin dilsel eşdeğerlik çalışması 32 İngilizce öğretmeni, test-tekrar test çalışması 86, ölçüt bağıntılı geçerlik çalışması ise 149 lise öğrencisi üzerinde yürütülmüştür. Ölçeği uyarlama aşamasında, Cronbach'ın alfa iç tutarlık güvenirlik katsayısı, pearson momentler çarpım korelasyon katsayısı ve 
doğrulayıcı faktör analizi yapılmıştır. Ölçeğin geçerlik ve güvenirlik çalışmalarından elde edilen verilerin analizi için SPSS 20 ve LISREL 8.8 paket programları kullanılmıştır.

\section{Bulgular}

Bilinçli başa çıkma ölçeğinin dilsel eşdeğerliğinden elde edilen bulgulara göre, Türkçe ve orijinal form puanları arasındaki ilişkinin farkındalık alt boyutu için .92, dikkati dağıtma alt boyutu için .91, olumsuz duyguları önleme alt boyutu için .87, kendini yapıcı olarak ortaya koyma alt boyutu için .90 olduğu belirlenmiştir. Ölçeğin yapı geçerliliği için Doğrulayıcı Faktör Analizi (DFA) uygulanmıştır. DFA sonucunda ki-kare değerinin $\left(\mathrm{x}^{2}=639.87, \mathrm{~N}=283, \mathrm{df}=221, \mathrm{p}=0.00\right)$ anlamlı olduğu görülmüştür. Uyum indeks değerleri ise $\mathrm{RMSEA}=.076, \mathrm{CFI}=.88, \mathrm{IFI}=.88, \mathrm{GFI}=.85, \mathrm{SRMR}=.074$ olarak bulunmuştur. Bilinçli başa çıkma ölçeğinin ölçüt bağıntılı geçerliği için ergenler için başa çıkma ölçeği ile arasındaki ilişkiye bakılmıştır. Bilinçli başa çıkma ölçeğinin alt boyutları ile ergenler için başa çıkma ölçeğinin aktif başa çıkma alt boyutu arasında pozitif yönde bir ilişki olduğu bulunmuştur (.23 ile .40 arasında). Buna karşın kaçınan başa çıkma ile olumsuz başa çıkma alt boyutları arasında bir ilişki bulunmamıştır. Ölçeğin güvenirliği Cronbach's Alfa Katsayısı ve Madde Toplam Korelasyon Katsayısı ile hesaplanmıştır. Bilinçli başa çıkma ölçeğinin Cronbach's Alfa İç Tutarlılık Güvenirlik Katsayısı farkındalık alt boyutu için .71, dikkati dağıtma alt boyutu için .79, olumsuz duyguları önleme alt boyutu için .72, kendini yapıcı olarak ortaya koyma alt boyutu için .71 olarak bulunmuştur. Madde-Toplam Korelasyonlarının Bilinçli başa çıkma ölçeği farkındalık alt boyutu için .31-.57, dikkati dağıtma alt boyutu için .33-.69, olumsuz duyguları önleme alt boyutu için $.38-.53$, kendini yapıcı olarak ortaya koyma alt boyutu için $.38-.59$ arasında değiştiği saptanmıştır.

\section{Sonuç}

Çalışmadan elde edilen sonuçlar; bilinçli başa çıkma ölçeğinin Türkçe formunun lise öğrencileri için geçerli ve güvenilir bir ölçme aracı olduğunu göstermektedir. Bu anlamda, lise öğrencileri için yapılacak çalışmalarda bilinçli başa çıkma ölçeği kullanılabilir. 